\title{
Zoogeographic relationships of Magellan Nudibranchia (Mollusca: Opisthobranchia) with particular reference to species from adjacent regions*
}

\author{
MICHAEL SCHRÖDL \\ Zoologische Staatssammlung München, Münchhausenstr. 21, 81247 München, Germany.
}

\begin{abstract}
SUMMARY: Extensive recent collections and taxonomical revisions provide a basis for the first zoogeographical analysis of Magellan Nudibranchia. Using 36 of 57 nominal species described in this area, the degree of endemism has been decreased from $70 \%$ to $31 \%$. Very close faunistic relationships to northern Argentina are evident as five of six known species (83\%) are shared with the Magellan Province. With a 43\% overlap of Magellan species in the southern part of the Peruvian faunal Province (44 species), this area shows a transitional character between cold- and warm-temperate waters. Only three of 36 Magellan species are found in common with the high Antarctic (ca. 30 species), revealing a low faunal similarity of about $10 \%$. High Antarctic waters are characterized by high nudibranch endemism (about $80 \%$ ). Of the ten nudibranch species reported from South Georgia, two are exclusively shared with Magellan, two with high Antarctic and three with both Magellan and Antarctic waters, indicating transitional, Subantarctic conditions. One species is endemic to South Georgia, two other species are insufficiently known and may or may not be endemic. Generally, the Antarctic Convergence appears to be a distributional barrier for Magellan nudibranchs. In contrast, some Antarctic nudibranch species extend far into the Atlantic, obviously with cold Antarctic deep water currents. Coastal, cold temperate Magellan nudibranchs have relatively low affinities to the deep water fauna off Argentina, which seems to be predominantly submerged Antarctic species, but this bathymetrical zonation needs to be further investigated.
\end{abstract}

Key words: Mollusca, Opisthobranchia, Nudibranchia, Magellan Province, Antarctica, Zoogeography.

RESUMEN: Relaciones zOOgEOGRÁficas de Nudibranchia (Mollusca: Opisthobranchia) de Magallanes CON REFeRENCIA ESPECIAL A LAS ESPECIES DE REGIONES ADYACENTES. - Recolecciones extensivas y revisiones taxonómicas actuales forman la base del primer análisis zoogeográfico de Nudibranchia magallánicos. Utilizando 36 de 57 especies nominales descritas de esta área, el grado de endemismo ha bajado desde 70\% a 31\%. Existen relaciones faunísticas muy próximas con el norte de Argentina ya que cinco de las seis especies conocidas (83\%) son comunes con la Provincia Magallánica. Las especies magallánicas contribuyen $43 \%$ de las especies conocidas de la parte sur de la Provincia faunistíca Peruana (44 en total), indicando el carácter de transición de esta área entre aguas templado-frías y cálidas. Sólo tres de 36 especies magallánicas son comunes con zonas al sur de la Convergencia Antártica (ca. 30 especies), resultando una afinidad faunística muy baja, de aproximadamente $10 \%$. Las aguas antárticas se caracterizan por un muy alto nivel de endemismo de nudibranquios (ca. 80\%). De las diez especies de nudibranquios citadas en Georgia del Sur, dos son comunes con áreas magallánicas exclusivamente, dos con la Antártida y tres con aguas antárticas y magallánicas, señalando condiciones de transición, subantárticas. Una espécie es endémica de Georgia del Sur, otras dos se conocen de manera deficiente, por lo que existe la posibilidad de que también sean endémicas. En general, la Convergencia Antártica parece un límite distribucional para nudibranquios magallánicos. Sin embargo, algunas especies de nudibranquios antárticos se extienden mucho hacia el Atlántico, obviamente con aguas antárticas profundas. Los nudibranquios magallánicos de las zonas templadas-frías sublitorales tienen relativamente poca afinidad con la fauna del talud argentino, que parece dominada por especies antárticas sumergidas, pero esta zonación batimétrica necesita ser estudiada de forma más extensa en el futuro.

Palabras clave: Mollusca, Opisthobranchia, Nudibranchia, Provincia Magallánica, Antártida, zoogeografía.

*Accepted January 5, 1999. 


\section{INTRODUCTION}

Nudibranchs are important members of many benthic communities due to their high species diversity, abundance and direct influences on community structure as selective predators of sessile filtering organisms (e.g. Clark, 1975; Todd, 1981). In the Magellan faunal Province, referring to the Patagonian shelf south of about $41^{\circ} \mathrm{S}$ on both the Pacific (Chiloé Island, Canal Calbuco) and Atlantic side (Península Valdés) including the Falkland Islands (see discussion in Brattström and Johanssen, 1983), nudibranchs were collected during several international expeditions during the last and at the beginning of this century. D'Orbigny (1835-46) was the first naturalist externally describing nominal nudibranch species during his "Voyage dans L'Amérique Méridionale". He was followed by Couthouy (in Gould, 1852, 1856), Cunningham (1871), Abraham (1877), and Rochebrune and Mabille (1891) who added a large number of poorly described additional species. Bergh (1884, 1894; 1898), Eliot (1907) and Odhner (1926) gave more detail, examining internal organs, especially radular and genital features as they continued establishing new species. Studying opisthobranchs collected during the Lund University Chile Expedition, Marcus (1959) gave detailed descriptions of 25 species from southern Chile, nine of them new to science, and briefly discussed zoogeographic aspects. Later, Marcus and Marcus (1969) redescribed a few species collected from Argentina by the "Vema" Expedition.

In total, more than 50 nudibranch species have been reported from the Magellan Province, however, most of them are inadequately described or established on just a single or very few specimens from the type locality. As biogeography crucially depends on solid taxonomic and distributional knowledge (Briggs, 1987), no comprehensive zoogeographical studies have been undertaken on Magellan nudibranchs.

Recently, several scientists started to collect material and critically revise dubious Magellan nudibranch species (Fischer and Ortea, 1996; Millen and Schrödl, in review; Muniaín et al., 1991, 1996; Muniaín and Ortea, 1998; Muñoz et al., 1996; Schrödl, 1996b, 1997a, 1997b, 1997c, in press $a$, in press $b$, in press $c)$. Nudibranch collections during the Joint Magellan "Victor Hensen" Campaign 1994 yielded few specimens, but established the southernmost records and provided material of several poorly known species (Schrödl, 1996a). On this basis, the present study analyzes the biogeographic relations of Magellan Nudibranchia to adjacent regions, especially to the nearby Subantarctic and Antarctic waters.

\section{MATERIAL AND METHODS}

This study considers distributional data of 36 Magellan nudibranch species regarded to be trustworthy. The basis for this compilation are extensive personal collections carried out in coastal Magellan waters, mainly using SCUBA, from 1991 to 1996 (see Schrödl, 1996b). Additional specimens were dredged from coastal and deeper waters of the Magellan Strait and Beagle Channel area during the Joint Magellan "Victor Henson" Campaign 1994 using Agassiz trawls (see Schrödl, 1996a). Material collected by individual workgroups during the same expedition has not yet been studied.

Taxonomic and distributional information on nudibranchs from the Magellan and Peruvian Provinces was mainly taken from Schrödl (1996b) and supplemented by relevant recent studies (Cervera, 1997; Fischer and Ortea, 1996; Fischer et al., 1997; Millen and Schrödl, in review; Muniaín et al., 1996, Muniaín and Ortea, 1998; Muñoz et al., 1996; Schrödl, 1996a, 1996c, 1997a, 1997b, $1997 \mathrm{c}$; in press a, in press $\mathrm{b}$, in press c, in press d; Schrödl and Millen, in press) and unpublished data of the author ${ }^{1}$. The nudibranch fauna of northern Argentina and of Subantarctic islands has not yet been reviewed, thus data from original studies (i.e. Bergh, 1894; Martens and Pfeffer, 1886; Odhner, 1926; Franceschi, 1928; Carcelles, 1944; Marcus and Marcus, 1969; Kaiser, 1980) are used. The taxonomy and distribution of many Antarctic nudibranch taxa was recently revised by Wägele (e.g. 1987, 1989a, 1989b, 1990, 1991, 1995) and Cattaneo-Vietti (1991). In the present study a species list given by Wägele (1993) is used, considering recent taxonomical results (i.e. García et al., 1993; Wägele, 1995; Schrödl, 1996b).

\footnotetext{
${ }^{1}$ Diaulula vestita (Abraham, 1877), Phidiana attenuata Couthouy in Gould, 1852, and Doto sp. 1 listed by Schrödl, (1996 b, 1997 c) have been omitted being in synonymy with other species. Of several dubious Magellan Cadlina species only C. sparsa (Odhner, 1921) and C. magellanica Odhner, 1926 seem trustworthy, the latter being in synonymy with C. falklandica Odhner, 1926 (see Schrödl, 1996 b, in press c); a specimen from South Georgia assigned to $C$. falklandica by Odhner (1926) differs from all Magellan cadlinids and also from C. kerguelensis Thiele, 1912 from Kerguelen. A detailed revision of tritoniid species will be published separately (see Muniaín and Schrödl, 1999).
} 
TABLE 1. - Distribution of Magellan nudibranchs. Species personally collected or found during the "Victor Hensen Campaign 1994" are indicated by an asterisk (PerP $=$ Peruvian Province; CPat $=$ Chilean Patagonia, $41^{\circ}-52^{\circ} \mathrm{S} ;$ Mag $=$ Magellan Strait area, Patagonia south of $52^{\circ} \mathrm{S}$; Falk = Falkland Islands; APat = Argentinian Patagonia south of Península Valdés to 52 ${ }^{\circ}$; NArg = Argentina north of Península Valdés; $\mathrm{SGe}=$ South Georgia Island; Ant = Antarctica without Subantarctic islands; ArS = Argentinian continental slope):

\begin{tabular}{|c|c|c|c|c|c|c|c|c|c|}
\hline & CPat & Mag & Falk & APat & PerP & NArg & SGe & Ant & $\operatorname{ArS}$ \\
\hline *Acanthodoris falklandica Eliot, 1907 & $\mathrm{X}$ & $\mathrm{X}$ & $\mathrm{X}$ & & $\mathrm{X}$ & & & & \\
\hline *Aeolidia papillosa var. serotina Bergh, 1873 & $\mathrm{x}$ & $\mathrm{x}$ & $\mathrm{x}$ & $\mathrm{X}$ & $\mathrm{x}$ & & & & \\
\hline *Ancula fuegiensis Odhner, 1926 & $\mathrm{x}$ & $\mathrm{x}$ & & & $\mathrm{X}$ & & & & \\
\hline *Anisodoris fontaini (D’Orbigny, 1837) & $\mathrm{x}$ & $\mathrm{x}$ & & $\mathrm{X}$ & $\mathrm{x}$ & $\mathrm{X}$ & & & \\
\hline *Anisodoris punctuolata (D’Örbigny,1837) & $\mathrm{x}$ & $\mathrm{x}$ & & $\mathrm{x}$ & $\mathrm{x}$ & & & & \\
\hline *Austrodoris kerguelenensis (Bergh,1884) & & $\mathrm{x}$ & $\mathrm{X}$ & & & & $\mathrm{X}$ & $\mathrm{X}$ & $\mathrm{X}$ \\
\hline *Cadlina magellanica Odhner, 1926 & & $\mathrm{x}$ & $\mathrm{x}$ & & & & & & \\
\hline${ }^{*}$ Cadlina sparsa $(\text { Odhner, } 1921)^{1}$ & $\mathrm{X}$ & & & $\mathrm{X}$ & $\mathrm{X}$ & & & & \\
\hline *Corambe lucea Marcus, 1959 & $\mathrm{x}$ & & & & $\mathrm{X}$ & & & & \\
\hline Cuthona georgiana Pfeffer in Martens \& Pfeffer, 1886 & $\mathrm{x}$ & & & & & & $\mathrm{X}$ & $\mathrm{X}$ & \\
\hline Cuthona odhneri Marcus, 1959 & $\mathrm{x}$ & & & & & & & & \\
\hline *Cuthona sp. \#2 (see Schrödl, 1996b) & $\mathrm{x}$ & & & & $\mathrm{X}$ & & & & \\
\hline *Cuthona valentini (Eliot, 1907) comb. nov. & & $\mathrm{X}$ & $\mathrm{X}$ & & & & & & \\
\hline *Diaulula hispida (D’Orbigny, 1837) & $\mathrm{X}$ & $\mathrm{x}$ & & $\mathrm{X}$ & $\mathrm{X}$ & & & & \\
\hline Doris falklandica (Eliot, 1907) & & & $\mathrm{X}$ & & & & & & \\
\hline *Doto uva Marcus, $1955^{2}$ & $\mathrm{X}$ & & & & $\mathrm{X}$ & & & & \\
\hline Eubranchus agrius Marcus, 1959 & $\mathrm{x}$ & & & & & & & & \\
\hline Eubranchus falklandicus (Eliot, 1907) & & & $\mathrm{X}$ & & & & & & \\
\hline *Eubranchus fuegiensis Odhner, 1926 & & $\mathrm{X}$ & & & & & & & \\
\hline *Flabellina falklandica (Eliot, 1907) & $\mathrm{X}$ & $\mathrm{X}$ & $\mathrm{X}$ & & & & $\mathrm{X}$ & & \\
\hline * Gargamella immaculata Bergh, 1894 & $\mathrm{x}$ & $\mathrm{x}$ & & $\mathrm{X}$ & $\mathrm{X}$ & $\mathrm{X}$ & & & \\
\hline * Geitodoris patagonica Odhner, 1926 & & $\mathrm{X}$ & $\mathrm{X}$ & $\mathrm{X}$ & & & & & \\
\hline *Holoplocamus papposus Odhner, 1926 & $\mathrm{X}$ & $\mathrm{x}$ & & & $\mathrm{X}$ & $\mathrm{X}$ & & & \\
\hline Neodoris claurina Marcus, 1959 & $\mathrm{x}$ & & & & & & & & \\
\hline Okenia angelensis Lance, $1966^{1}$ & $\mathrm{x}$ & & & & $\mathrm{X}$ & & & & \\
\hline *Phidiana lottini (Lesson, 1831) & $\mathrm{x}$ & & & & $\mathrm{x}$ & & & & \\
\hline Phidiana patagonica (D’Orbigny, 1837) & & $\mathrm{X}$ & & $\mathrm{X}$ & & & & & \\
\hline *Polycera priva Marcus, 1959 & $\mathrm{X}$ & & & & & & & & \\
\hline *Polycera marplatensis Franceschi, $1928^{3}$ & & & & $\mathrm{X}$ & & $\mathrm{x}$ & & & \\
\hline *Rostanga pulchra MacFarland, $1905^{1}$ & $\mathrm{x}$ & & & $\mathrm{X}$ & $\mathrm{x}$ & & & & \\
\hline *Thecacera darwini Pruvot-Fol, 1950 & $\mathrm{x}$ & $\mathrm{x}$ & & & $\mathrm{X}$ & & & & \\
\hline *Tritonia sp. & $\mathrm{x}$ & & & & $\mathrm{x}$ & & & & \\
\hline *Tritonia challengeriana Bergh, 1884 & $\mathrm{x}$ & $\mathrm{X}$ & $\mathrm{X}$ & & & $\mathrm{X}$ & $\mathrm{X}$ & $\mathrm{X}$ & \\
\hline *Tritonia odhneri Marcus, 1959 & $\mathrm{x}$ & & & & $\mathrm{X}$ & & & & \\
\hline *Tritonia vorax (Odhner, 1926) & & $\mathrm{X}$ & & & & & $\mathrm{X}$ & & $\mathrm{x}$ \\
\hline *Tyrinna nobilis Bergh, 1898 & $\mathrm{X}$ & & & $\mathrm{X}$ & $\mathrm{X}$ & & & & \\
\hline
\end{tabular}

${ }^{1}$ also known from the northeastern Pacific. ${ }^{2}$ also ocurring in Brazil and the Caribbean. ${ }^{3}$ also in Brazil.

\section{RESULTS}

269 nudibranchs were found in coastal Magellan waters during personal collecting, nine additional specimens came from the "Victor Hensen" expedition 1994 (see Schrödl, 1996a). The total of 278 specimens is identified as belonging to 28 different species (see Table 1). In addition to these 28, eight further Magellan species are regarded to be distinct species with a reasonable certainty (Table 1 ). This leads to a total of 36 nudibranch species reported from Magellan waters which are considered within this study. Table 1 shows their distributional ranges, dividing the Magellan Province into the Pacific and Atlantic coasts from $41^{\circ} \mathrm{S}$ to $52^{\circ} \mathrm{S}$, the southernmost tip of Patagonia south of $52^{\circ} \mathrm{S}$, and the Falkland Islands.

Only 11 of the 36 species (31\%) are endemic within the Magellan Province (Table 1): Neodoris claurina Marcus, 1959, Cuthona odhneri Marcus, 1959 and
Eubranchus agrius Marcus, 1959 (the conspecifity to E. agrius reported from New Zealand by Miller (1971) remains to be confirmed by studying living specimens from Chile) are only known from their type locality, Chiloé Island. Polycera priva Marcus, 1959 seems limited to the Chilean fjord region (Fig. 1A) and Eubranchus fuegiensis Odhner, 1926 to the southernmost tip of Patagonia (Fig. 1A). Eubranchus falklandicus Eliot, 1907 and Doris falklandica (Eliot, 1907) have just single records from the Falklands, Cadlina magellanica and Cuthona valentini (Eliot, 1907) comb. nov. [herein transferred from Tergipes (see Cattaneo-Vietti, 1991) to Cuthona due to cerata arranged in short rows (see Eliot, 1907; personal data)] occur from the Magellan Strait to the Falklands, Geitodoris patagonica Odhner, 1926 additionally in Argentinian Patagonia (Fig. 1A), and Phidiana patagonica (D’Orbigny, 1837) is reported from Argentinian Patagonia to the Magellan Straits. 

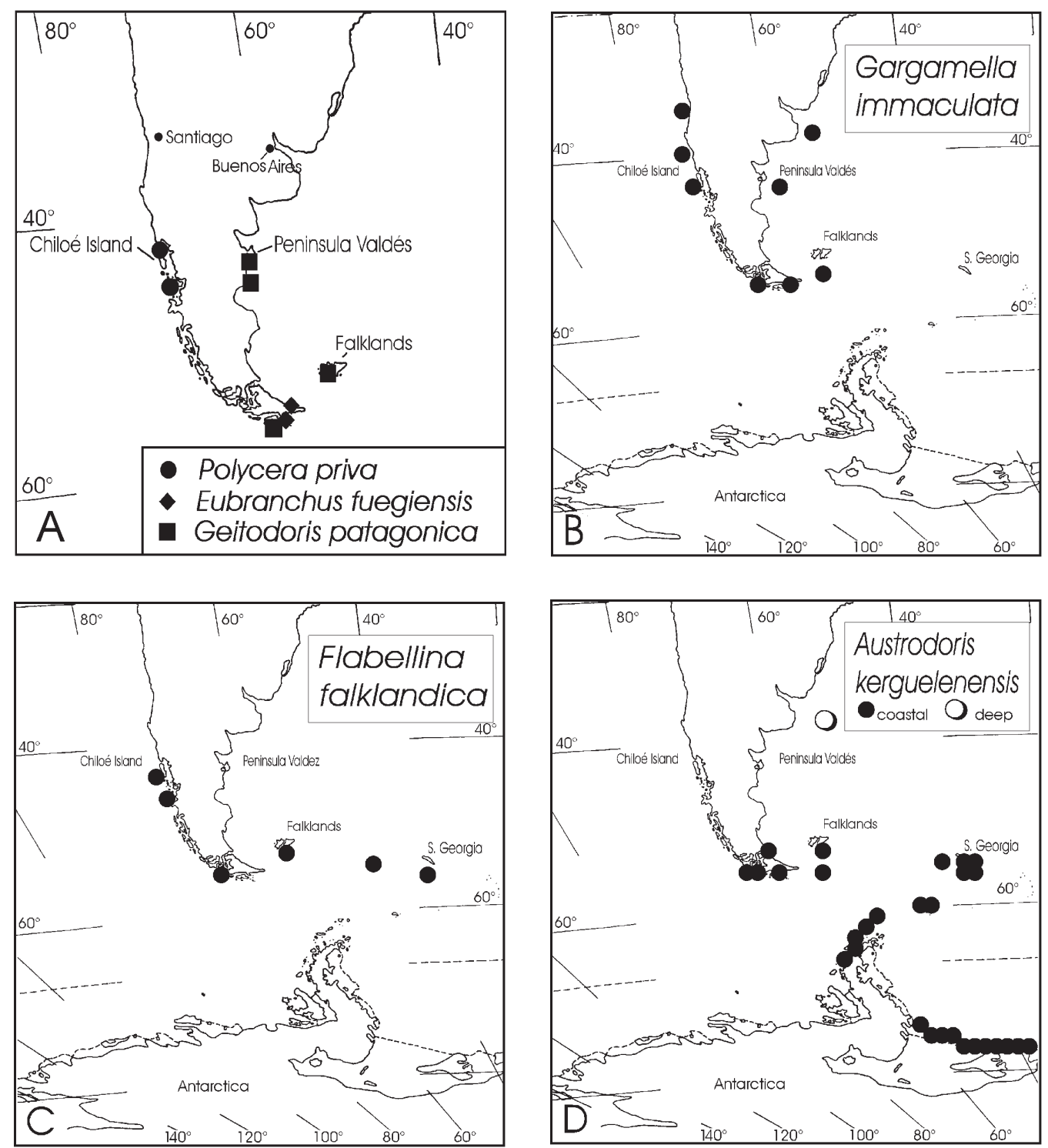

FIG. 1. - Distribution of Magellan Nudibranchia. A. Three apparently endemic species: Polycera priva seems limited to the Chilean fjord region, Eubranchus fuegiensis is only known from Tierra del Fuego and the Beagle Channel, and Geitodoris patagonica occurs in the Atlantic sector of the Magellan Province. B. Gargamella immaculata, having a wide Magellan distribution with extensions into central Chile and northern Argentina. C. Magellan and Subantarctic distribution of Flabellina falklandica (record from Crozet Island omitted). D. The circumantarctic (not all records indicated) Austrodoris kerguelenensis only occurs coastally in southernmost Patagonia. In lower latitudes it submerges, being reported from $740 \mathrm{~m}$ depth off Mar del Plata.

TABLE 2. - Zoogeographic relationships of Nudibranchia of the Magellan Province (MP) to adjacent regions.

\begin{tabular}{|c|c|c|c|c|c|c|}
\hline & $\begin{array}{l}\text { Magellan } \\
\text { Province }^{1}\end{array}$ & $\begin{array}{l}\text { Peruvian } \\
\text { Province }^{2}\end{array}$ & $\begin{array}{l}\text { Northern } \\
\text { Argentina }^{3}\end{array}$ & $\begin{array}{c}\text { South } \\
\text { Georgia }^{4}\end{array}$ & $\underset{\text { Antarctic }^{5}}{\text { High }}$ & $\begin{array}{c}\text { Deep sea } \\
\text { Argentina }^{6}\end{array}$ \\
\hline Species number & 36 & 44 & 7 & 10 & ca. 30 & 4 \\
\hline Endemic species & $31 \%$ & $39 \%$ & $0 \%$ & $10 \% ?$ & ca. $80 \%$ & $25 \%$ \\
\hline Species shared with MP & 36 & 19 & 6 & 5 & 3 & 2 \\
\hline Species shared with MP/ known species & $100 \%$ & $43 \%$ & $83 \%$ & $50 \%$ & ca. $10 \%$ & $50 \%$ \\
\hline
\end{tabular}

Main data sources (see also "Material and Methods"):

${ }^{1}$ Schrödl, 1996a, 1996b, 1997b, 1997c; in press a, in press b, in press c; Schrödl and Millen in press; this study.

${ }^{2}$ Schrödl, 1996b, 1996c, 1997a, 1997b, 1997c; in press d; this study.

${ }^{3}$ Odhner, 1926; Schrödl, 1996b.

${ }^{4}$ Odhner, 1926; Wägele, 1993; this study.

${ }^{5}$ Wägele, 1993, modified.

${ }^{6}$ Kaiser, 1980; Wägele, 1993. 
The other 25 species are more widespread: Ancula fuegiensis Odhner, 1926 and Thecacera darwini Pruvot-Fol, 1950 occur from the southern tip of Patagonia to central and even northern Chile, respectively. A number of Magellan species, e.g. Gargamella immaculata Bergh, 1894, occurring in both Atlantic and Pacific waters also extend north into the warm temperate Peruvian Province (Fig. 1B; Tab. 1). Other species, e.g. Phidiana lottini (Lesson, 1831) and Corambe lucea Marcus, 1959, may be Peruvian in their distribution, extending their southernmost ranges near Chiloé Island. In Argentina, several Magellan species, e. g. Tyrinna nobilis Bergh, 1898, have their known northern limit at Península Valdés. Others, e.g. Gargamella immaculata Bergh, 1894, Anisodoris fontaini (D'Orbigny, 1837) and Holoplocamus papposus Odhner, 1926 extend considerably into warm temperate Atlantic waters of northern Argentina. Gargamella immaculata also inhabits the submersal Burdwood Bank south of the Falklands (Fig. 1B). Flabellina falklandica is known from Chilean Patagonia, the Falklands and also reaches South Georgia (Fig. 1C) and Crozet Islands. Austrodoris kerguelenensis (Bergh, 1884), Tritonia challengeriana Bergh, 1884 (synonym of T. antarctica Pfeffer in Martens and Pfeffer, 1886; see Schrödl, 1996b) and Cuthona georgiana Pfeffer in Martens and Pfeffer, 1886 occur in Patagonia, South Georgia and the high Antarctic (see Fig. 1D). Tritonia vorax Odhner, 1926 ranges from the Beagle Channel, over the Burdwood Bank to South Georgia, not only in coastal, but also in deeper waters.

The zoogeographical comparison (Table 2) shows a relatively high species number (44) and endemism (39\%) for the Peruvian faunal Province. The taxonomically better studied Magellan Province has fewer species (36) and a lower nudibranch endemism $(31 \%)$. No endemic nudibranchs are known from the warm temperate waters of northern Argentina. The Subantarctic South Georgia Island possesses at least one endemic nudibranch species, while nudibranch endemism is highest (about 80\%) in high Antarctic waters (Table 2).

The relations of Magellan species to adjacent areas is indicated by the number of shared species (Tab. 2). Additionally, Table 2 gives the ratio number of common species to total species number of the respective area; this documents the relative influence of Magellan nudibranch species within the respective faunas. With 83\%, Magellan species predominate in northern Argentina. The Peruvian fau- nal Province and South Georgia are both considerably influenced by Magellan species (Table 2). This is in clear contrast to the high Antarctic where only $10 \%$ of the known nudibranch species are shared with the Magellan faunal Province.

Only four species are reported from deeper waters of the Argentinian continental slope, of which one, Bathydoris patagonica Kaiser, 1980 seems to be endemic. Two species, T. vorax and $A$. kerguelenensis, are shared with cold temperate coastal, Magellan waters. Both species, however, only occur coastally on the southernmost tip of Patagonia (see Fig. 1D; Tab. 1). T. vorax has a Subantarctic, A. kerguelenensis a circumantarctic distribution, along with the remaining species Bathydoris clavigera Thiele, 1912.

\section{DISCUSSION}

Extensive recent collections and taxonomical revisions enable a first zoogeographic account of Magellan nudibranchs, regarding their endemism and faunal relationships. In former studies (Carcelles and Williamson, 1951; Marcus, 1959) 32 of 46 species $(70 \%)$ appeared to be endemic. Based on the species list given in Table 1 , only 11 of 36 species $(31 \%)$ exclusively occur within the Magellan faunal province. Five of them are still only known from their type localities (Tab. 1), indicating collecting bias. Four species with more than a single record appear to be endemic within the Atlantic area, including the Falklands (Malvinas), eastern Magellan Straits and Beagle Channel, one to the Atlantic side of Tierra del Fuego, and two in Chilean Patagonia (see Fig. 1A; Tab. 1). This indicates a certain faunal separation into Pacific and Atlantic elements. Interestingly, not a single nudibranch species fits within the limits often proposed for the Magellan faunal Province that is, exclusively occurring south from $41^{\circ} \mathrm{S}$ on both the Atlantic and Pacific coasts of South America (see discussion in Brattström and Johanssen, 1983).

Instead, many species formerly considered to be endemic to Magellan waters or known from a single locality were recently found to have a much wider range: a total of 10 species and Aeolidia papillosa var. serotina Bergh, 1873 occur throughout the Magellan Province. On the Pacific side, they range northwards with the cold-temperate Humboldt Current waters, favoured by areas of strong upwelling, into central and even northern Chile, the southern 
part of the Peruvian faunal Province (Schrödl, 1996b; 1997a; this study, see Fig. 1B). These species, as well as Ancula fuegiensis and Thecacera darwini which appear to be limited to Pacific waters (Fischer and Ortea, 1996; Schrödl, 1996b), confirm the general tendency of Magellan marine organisms to extend into a transitional area off central Chile (Brattström and Johanssen, 1983).

On the Atlantic side a similar phenomenon occurs: several wide-ranging Magellan species, Anisodoris fontaini, Gargamella immaculata, Holoplocamus papposus, and Tritonia challengeriana extend north of the Valdés Península to northern Argentina and the La Plata river (see Fig. 1B). Polycera marplatensis (as P. quadrilineata var. marplatensis) occurs from Argentinian Patagonia (Schrödl, 1996b: 31) to Brazil (see Muniaín and Ortea, 1998). From northern Argentina, no endemic species and only a single member of the Atlantic warm water fauna, Mariona cucullata Gould, 1852 (= T. occidentalis Bergh, 1884; see Odhner, 1926, 1934), is known. With a total of only six species, northern Argentina is still very poorly studied. As five of these six species (83\%) are shared with the Magellan region and at least four species show an extended Magellan distribution, however, this area is clearly predominated by Magellan nudibranchs.

The Antarctic nudibranch fauna is comprised of about 30 species from south of the Antarctic Convergence excluding South Georgia and other Subantarctic islands (Wägele, 1993, modified). The short geographical distance between South America and the Antarctic Peninsula and the potentially high dispersal ability of planktonic nudibranch larvae would suggest close faunal affinities. There are, however, only three species (Table 1; Fig. 1D) in common between cold temperate (=coastal) Magellan (36 species) and Antarctic waters (30 species): while Austrodoris kerguelenensis was critically revised recently (Wägele, 1990), taxonomic studies remain to be done on T. challengeriana and Cuthona georgiana (see Cattaneo-Vietti, 1991; Schrödl, 1996 b). This results in a strikingly low nudibranch similarity of $10 \%$, coinciding with values for shelled gastropod species given by Linse (1997). On generic level, Millen and Schrödl (in review) showed Magellan nudibranch genera to be even closer related to the Aleutian fauna than to that of Antarctica. The Antarctic Convergence thus has been a rather strict distributional boundary for temperate nudibranchs.
The molluscan fauna of South Georgia was characterized to have 1) low affinities to temperate faunas (Powell, 1951) and 2) high rates of endemism (Dell, 1972). However, this does not hold true for nudibranchs. Of a total of ten nudibranch species reported from South Georgia, two species are common with the Magellan province, but not with the Antarctic: Flabellina falklandica was indicated to have northern Pacific ancestors (Millen and Schrödl, in review), but recently shows a wide Magellan distribution from Chiloé Island over southern Patagonia and the Falklands, and additionally occurs in South Georgia and Crozet Island (see Fig. 1C). It has obviously spread there with the help of circumantarctic currents (Marcus, 1959). Dispersal by rafting seems possible since F. falklandica was found in abundance on kelp feeding hydroids which grow on the fronds (see Millen and Schrödl, in review). The second species, Tritonia vorax, occurs in deeper waters $(100 \mathrm{~m}-360 \mathrm{~m})$ off the Beagle Channel, the Burdwood Bank and South Georgia, but is not reported from other locations south of the Antarctic Convergence. Three species from South Georgia (A. kerguelenensis, T. challengeriana, $C$. georgiana), are shared with both Magellan and Antarctic waters (see Fig. 1D), and two, Bathydoris clavigera and Tritoniella belli Eliot, 1907 are circumantarctic species. This confirms the transitional, Subantarctic character of the nudibranch fauna of South Georgia suspected by Marcus (1959), with close relations to both Magellan and Antarctic waters. As Wägele (1991) pointed out, there is no or only a low nudibranch endemism in South Georgia. Cuthona antarctica Pfeffer in Martens and Pfeffer, 1886 may be endemic (Tab. 2), but, together with specimens of Cuthona schraderi (see Cattaneo-Vietti, 1991) from South Georgia, requires taxonomical revision. Austrodoris georgiensis established on a single specimen from South Georgia by García et al. (1993) is here considered to belong to the circumantarctic and very variable A. kerguelenensis as redescribed by Wägele (1990, 1993). A specimen previously assigned to Cadlina falklandica Odhner, 1926 differs from all other southern cadlinids and thus is described as a new species (Schrödl, in press c); this is the only nudibranch species so far known to be endemic to South Georgia.

Distributional studies on Magellan and Antarctic nudibranchs not only have to consider latitudinal but also bathymetrical aspects. It seems possible for cold adapted, Antarctic nudibranch species to submerge in lower geographical latitudes and inhabit the South American continental slope, probably due 
to intermediate Antarctic cold water currents flowing into the Atlantic. This is indicated by the occurrence of the circumantarctic Tritoniella belli (as $T$. sinuata Eliot, 1907; see Wägele, 1989 b) north to the Shag Rock Bank (53여 $; 160 \mathrm{~m}$ depth; Odhner, 1926). The circumantarctic and eurybathic, eye possessing Bathydoris clavigera (as B. argentina Kaiser, 1980; see Wägele, 1989 a) extends north to a latitude of about $44^{\circ} \mathrm{S}$ off Argentina, where it was collected between 400-1200 m depth (Kaiser, 1980). Austrodoris kerguelenensis probably even occurs far north, off Mar del Plata (37 $\left.36^{\prime} \mathrm{S}\right)$, but in $740 \mathrm{~m}$ depth (Bouchet, 1977: as A. macmurdensis; see Wägele, 1991; 1993; this study, see Fig. 1D). Until now, nothing is known about the extension and history of these deep water populations.

Interestingly, only two of 36 Magellan species were found in deeper waters off Argentina (Table 1). Although representing 50\% of the four species known from the Argentinian slope (Table 2), neither are exclusively shared with coastal Magellan waters. Instead, all three non-endemic species show clear relationships to Subantarctic or Antarctic regions (Table 1). Thus the nudibranch fauna of the Patagonian shelf appears to have relatively low affinities to that of deeper areas which are strongly influenced by Antarctic species. The eye-lacking Bathydoris patagonica is apparently endemic to the Argentinian slope (see Kaiser, 1980), and may indicate the existence of a unique Argentinian deep-sea fauna. However, greater depths off South America are far too poorly known to draw final conclusions.

\section{ACKNOWLEDGEMENTS}

My thanks go to Sandra Millen (Vancouver) and Sebastian Gigglinger (München) for diving company under not always easy conditions and many discussions on the subject. Katrin Linse (Hamburg), Heike Wägele (Bochum) and Sandra Millen are warmly acknowledged for helpful comments on the manuscript. Special thanks are directed to Prof. W. Arntz (AWI) for kindly letting me participate in the IBMANT activities.

\section{REFERENCES}

Abraham, P.S. - 1877. Revision of the anthobranchiate Nudibranchiate Mollusca, with descriptions or notices of forty-one hitherto undescribed species. Proc. Zool. Soc. London: 196269.
Bergh, L.S.R. - 1884. Report on the Nudibranchiata. Rep. Sci. Res. Challenger Zool., 10: 1-151.

Bergh, L.S.R. - 1894. Die Opisthobranchien. Bull. Mus. Comp. Zool., 25: 125-235.

Bergh, L.S.R. - 1898. Die Opisthobranchier der Sammlung Plate. Zool. Jahrb. Suppl., 4: 481-582.

Bouchet, P. - 1977. Opisthobranches de profondeur de l'Océan Atlantique: II - Notaspidea et Nudibranchiata. J. Moll. Stud., 43: $28-66$

Brattström, H. and A. Johanssen. - 1983. Ecological and regional zoogeography of the marine benthic fauna of Chile. Report no. 49 of the Lund University Chile Expedition 1948-49. Sarsia, 68: 289-339.

Briggs, J.C. - 1987. Biogeography and Plate Tectonics. Elsevier, Amsterdam.

Carcelles, A.R. - 1944. Catálogo de los moluscos marinos de Puerto Quequén. Rev. Mus. La Plata N. S. Sec. Zool., 3: 233-309.

Carcelles, A.R. and S.I. Williamson. - 1951. Catálogo de los moluscos marinos de la Provincia Magallánica. Rev. Mus. Arg. Cienc. Nat. Cienc. Zool., 2: 225-383.

Cattaneo-Vietti, R. - 1991. Nudibranch Molluscs from the Ross Sea, Antarctica. J. Moll. Stud., 57: 223-228.

Cervera, J.L. - 1997. Janolus chilensis junior synonym of J. rebeccae Schrödl, 1996. Opisthobranch Newsl., 23: 29.

Clark, K.B. - 1975. - Nudibranch life cycles in the northwest Atlantic and their relationship to the ecology of fouling communities. Helgoländer Wiss. Meeresunters., 27: 28-69.

Cunningham, R.O. - 1871. Notes on the reptiles, Amphibia, fishes, Mollusca, and Crustacea obtained during the voyage of M.S. 'Nassau' in the years 1866-69. Trans. Linn. Soc. London, 27: 465-502.

Dell, R.K. - 1972. Antarctic benthos. Adv. Mar. Biol., 10: 1-216.

D’Orbigny, A. - 1835-1846. Voyage dans l'Amérique Méridionale exécuté pendant les années 1826-1833 par Alcide d'Orbigny. 5. Mollusques. Libraire de la Société Géologique de France, Paris.

Eliot, C.N.E. - 1907. Nudibranchs from New Zealand and the Falkland Islands. Proc. Malacol. Soc. London, 7: 327-361.

Fischer, M.A. and J. Ortea. - 1996. New records of the genus Ancula Loven, 1830 (Nudibranchia: Goniodorididae) on the American Pacific coast. Veliger, 39: 90-92.

Fischer, M.A., J.L. Cervera and J. Ortea. - 1997. First record of the genus Janolus Bergh, 1884 (Opisthobranchia: Arminacea: Zephyrinidae) from the Pacific coast of South America, with the description of a new species. Veliger, 40: 234-239.

Franceschi, G.J. - 1928. Una nueva forma de nudibranquio de la Argentina (Polycera quadrilineata var. marplatensis, n. var.). An. Mus. Hist. Nat. Buenos Aires, 34: 577-586.

García, F.J., J.S. Troncoso, J.C. García-Gomez and J.L. Cervera. 1993. Anatomical and taxonomical studies on the Antarctic nudibranchs Austrodoris kerguelenensis (Bergh, 1884) and A. georgiensis n. sp. from the Scotia Sea. Polar Biol., 13: 417-421.

Gould, A.A. - 1852 (1856, Atlas). United States exploring expedition during the years 1838-1842. Mollusca \& shells. U.S. Exploring Expedition, 12.

Kaiser, P. - 1980. Die Gattung Bathydoris Bergh 1884 in patagonischen Gewässern. Spixiana, 3: 43-51.

Linse, K. - 1997. Die Verbreitung epibenthischer Mollusken im chilenischen Beagle-Kanal. Ber. Polarforsch., 228: 1-131.

Marcus, E. - 1959. Lamellariacea und Opisthobranchia. Reports of the Lund University Chile Expedition 1948-49, No. 36. Lunds Univ. Arssk., 55: 1-133.

Marcus, Ev. and Er. Marcus. - 1969. Opisthobranchian and lamellarian gastropods collected by the "Vema". Am. Mus. Nat. Hist. Nov., 2368: 1-31

Martens, E. and G. Pfeffer. - 1886. Die Mollusken von Südgeorgien nach der Ausbeute der Deutschen Station 1882-83. Jahrb. Hamb. Wiss. Anst., 3: 65-135.

Millen, S. V. and M. Schrödl. - In review. On the genus Flabellina Voigt, 1834 from the Eastern Pacific. Zool. J. Linn. Soc.

Miller, M. C. - 1971. Aeolid nudibranchs (Gastropoda: Opisthobranchia) of the families Flabellinidae and Eubranchidae from New Zealand waters. Zool. J. Linn. Soc., 50: 311-337.

Muniaín, C., J. Ortea and G. Rodriguez. - 1991. Redescripción de Neodoris carvi Marcus, 1955 de las costas de Patagonia, con notas sobre las relaciones entre los géneros Archidoris y Neodoris. Iberus, 10: 105-111.

Muniaín, C., A. Valdés and J. Ortea. - 1996. Redescription of Tyrinna nobilis Bergh, 1898 (Opisthobranchia: Chromodoridi- 
dae) from Patagonia, Argentina. J. Moll. Stud., 62: 265-273.

Muniaín, C. and J. Ortea. - 1998. The taxonomic status and redescription of Polycera marplatensis Franceschi, 1928 (Nudibranchia: Polyceratidae) from Argentina. Veliger, 41: 142-147.

Muniaín, C. and M. Schrödl. - 1999. Taxonomic revision of Magellanic and Antarctic Tritoniidae. Abstracts of the Second International Workshop of Malacology, Menfi.

Muñoz, M.A., A. Valdés and J. Ortea. - 1996. The genus Okenia Menke, 1830 (Nudibranchia: Goniodorididae) in Chile. Haliotis, 25: 101-106.

Odhner, N.H. - 1926. Die Opisthobranchien. Further Zool. Res. Swed. Antarct. Exped. 1901-1903, 2: 1-100.

Odhner, N.H. - 1934. The Nudibranchiata. Brit. Antarct. Terra Nova Exped., 1910-1913, 7: 229-310.

Powell, A.W.B. - 1951. Antarctic and Subantarctic Mollusca: Pelecypoda and Gastropoda. Discovery Rep., 26: 47-196.

Rochebrune, A.T. and J. Mabille. - 1891. Mollusques. Mission Scient. Cap Horn, 6, Moll.: 1-192.

Schrödl, M. - 1996a. Opisthobranchs (Gastropoda) collected by the research vessel "Victor Hensen". Ber. Polarforsch., 160: 52-54.

Schrödl, M. - 1996b. Nudibranchia y Sacoglossa de Chile: Morfología exterior y distribución. Gayana Zool., 60: 17-62.

Schrödl, M. - 1996c. Janolus rebeccae, a new species of arminacean nudibranchs from northern Chile. Spixiana, 19: 293-300.

Schrödl, M. - 1997a. Range extensions of Magellanic Nudibranchs (Opisthobranchia) into the Peruvian Faunal Province. Veliger, 40: 38-42.

Schrödl, M. - 1997b. On the Magellanic nudibranch Gargamella immaculata Bergh, 1894, and its synonymy to G. latior Odhner, 1926. Spixiana 20: 81-92.

Schrödl, M. - 1997c. On the morphology of the Magellanic nudibranch Anisodoris fontaini (D'Orbigny, 1837), and its synonymy with A. tessellata Bergh, 1898. Veliger, 40: 228-233.

Schrödl, M. - In press a. Revision of dorid Nudibranchia collected during the French Cape Horn Expedition in 1882-1883, with discussion of the genus Geitodoris Bergh, 1891. Veliger.

Schrödl, M. - In press b. Taxonomic revision of the common South American nudibranch Anisodoris fontaini (D'Orbigny, 1837), with discussion of its systematic placement. J. Moll. Stud.

Schrödl, M. - In press c. Revision of the nudibranch gastropod genus Cadlina (Nudibranchia: Chromodorididae) from the Southern Ocean. J. mar. biol. Ass. UK.

Schrödl, M. - In press d. Hancockia schoeferti, a new dendronotoid nudibranch species from central Chile (Gastropoda: Nudibranchia: Hancockiidae). Spixiana.

Schrödl, M. and S.V. Millen - In press. Revision of the nudibranch gastropod genus Tyrinna Bergh, 1898 (Nudibranchia: Doridoidea). J. Nat. Hist.

Todd, C.D. - 1981. The ecology of nudibranch molluscs. Oceanogr. Mar. Ann. Rev., 19:141-234.

Wägele, H. - 1987. The distribution of some Antarctic nudibranchs (Opisthobranchia). J. Moll. Stud., 53: 179-188.

Wägele, H. - 1989a. A revision of the Antarctic species of Bathydoris Bergh, 1884 and comparision with other known bathydorids (Opisthobranchia, Nudibranchia). J. Moll. Stud., 55: 343-364.

Wägele, H. - 1989b. On the anatomy and zoogeography of Tritoniella belli Eliot, 1907 (Opisthobranchia, Nudibranchia) and the synonymy of T. sinuata Eliot, 1907. Polar Biol., 9: 235244.

Wägele, H. - 1990. Revision of the genus Austrodoris Odhner, 1926. (Gastropoda, Opisthobranchia). J. Moll. Stud., 56: 163180.

Wägele, H. - 1991. The distribution of some endemic Antarctic Nudibranchia. J. Moll. Stud., 57: 337-345.

Wägele, H. - 1993. New results on the systematics of Nudibranchia (Opisthobranchia, Gastropoda) from the southern polar seas. Boll. Malacologico, 29: 181-190.

Wägele, H. - 1995. The morphology and taxonomy of the Antarctic species of Tritonia Cuvier, 1797 (Nudibranchia: Dendronotoidea). Zool. J. Linn. Soc., 113: 21-46. 